\title{
The City in Cinema: A Global Perspective
}

\author{
David J. Edelman \\ School of Planning, College of Design, Architecture, Art \& Planning, University of Cincinnati, Cincinnati, OH, USA \\ Email: david.edelman@uc.edu
}

Received 15 April 2016; accepted 28 May 2016; published 1 June 2016

Copyright (C) 2016 by author and Scientific Research Publishing Inc.

This work is licensed under the Creative Commons Attribution International License (CC BY).

http://creativecommons.org/licenses/by/4.0/

(c) () Open Access

\begin{abstract}
Commercial cinema is a worldwide form of entertainment enjoyed by most of the planet's population and variety of cultures. Films are produced on six continents and marketed successfully internationally. However, cinema is more than a medium for telling stories of adventure, intrigue, comedy and romance. As most of the world's population now lives in cities, many films take place in urban settings, where a large number of those cities' physical and social problems are exposed. Commercial film, then, plays a useful role in determining how such issues can be confronted through the lenses of their many countries and cultures. That is, solutions to urban problems must be culturally sensitive. Moreover, as cities dominate life on planet Earth in the $21^{\text {st }}$ century far beyond what their population alone would warrant, they are at the core of some of the most influential films of the last century. This paper, then, is significant in that it looks at some of these urban focused films and identifies the universal themes they consider.
\end{abstract}

\section{Keywords}

Cinema, Film, Global, City, Urban Problems, Culture

\section{Introduction}

In a world in which more than $50 \%$ of all people live in cities and the urbanization rate is rapidly increasing, the cultural milieu of the city forms a tapestry of issues within which humanity's problems must be solved. Cities around the world have the same problems of transportation, the environment, social conflict and dislocation, land use planning, etc. Since these problems manifest themselves differently and must be tackled in various ways depending on the cultural context of the particular city, the urban planners who deal with them must be sensitive as well as skilled. Physical problems may have physical solutions, but social problems rarely do, and it is the purpose of this essay to demonstrate that cinema has a very special role in promoting the understanding and ultimate solution of urban ills.

The medium of film demonstrates these themes and generates discussion about them in an accessible and 
clear way to those of all ages, educational levels, cultures, religions, social structures, languages and levels of economic development. Commercial film, having as objectives to both inform and entertain, provides the ideal means to expand the understanding of the complexity, but universality, of urban issues and the variety of solutions available to not always solve, but at least ameliorate them.

Cities come in many forms-ancient and new, large and small, planned and spontaneous, homogeneous and diverse, poor and rich, concentrated and sprawled, tropical and arid, conflict ridden and peaceful, growing and declining. Their variety is as endless as are the people who inhabit them, and dealing with their problems has no single array of solutions.

Commercial film is a worldwide phenomenon attracting millions of viewers in theaters, on television and online. While the industry is dominated by Hollywood and Bollywood in terms of the number of films produced and their worldwide influence, commercial films are made in a dazzling variety of countries on six continents. Just as cities dominate life on planet Earth in the $21^{\text {st }}$ century, they are at the core of some of the most influential films of the last century. Let us, then, look at some of these films and the themes they consider.

\section{Urban Industrialization}

In Modern Times (USA, 1936) British-born Charlie Chaplin, one of the cinema’s first comic geniuses, portrayed the impact of urban industrialization as destructive and demeaning to the individual. Factory workers are often portrayed in film as exploited. Sally Field, for example, in Martin Ritt's Norma Rae (USA, 1979) portrays a factory worker who becomes involved in the labor union activities at the textile factory where she works after the health of her and her co-workers is compromised. This conflict extends to the image of the future city as well. Fritz Lang's Metropolis (Germany, 1927) shows a futuristic city sharply divided between the working class and the city planners (although the planners in the film are credited with far more power that they have ever had!). The novel solution is that the son of the city's mastermind falls in love with a working class prophet who predicts the coming of a savior to mediate their differences. While Ridley Scott's Blade Runner (USA, 1991) is set in the dystopian steel and microchip jungle of a future Los Angeles of humanoids and complex languages, Neill Blomkamp's Elysium (USA, 2013) suggests a societal split between the disenfranchised workers of a hellish Los Angeles contrasted with the privileged upper classes of a utopian suburban environment living in the ultimate gated community-a satellite circulating earth.

\section{Class Conflict}

Direct class conflict is another classic theme of the urban cinema. The hugely successful Slumdog Millionaire (UK/India, 2008), set in Mumbai (Bombay), centers on a teenager who grew up in the slums and becomes a contestant on the Indian version of "Who Wants to be a Millionaire?" He is arrested under suspicion of cheating, because it is assumed that he, an uneducated orphan who delivers tea to workers in a call center, could not possibly know the answers any other way. La Haine (France, 1995), directed by Mathieu Kassovitz, begins after a night of rioting on a dismal housing estate isolated on the northern outskirts of Paris and focuses on three close friends. They are an explosive working-class Jew, a handsome, soft-spoken Black, and a mercurial streetwise Arab. With little hope and few prospects for regular employment due to where they come from, the trio drift aimlessly, engaging in petty theft, and seething with aggressive resentment against an uncaring world. In Fernando Meirelles and Kátia Lund's City of God (Brazil, 20002), the seething conflict of the underclass in Rio de Janeiro's drug-ridden and crime infested favelas is portrayed with devastating effectiveness. Here, two boys growing up in a violent neighborhood take different paths: one becomes a photographer, the other a drug dealer.

\section{Race and Ethnicity}

Sometimes the conflict of population groups in cities has a strong racial or ethnic component. Spike Lee is a prominent director of urban cinema who tackles this theme head on. Do the Right Thing (USA, 1989) is set in the Bedford-Stuyvesant area of Brooklyn, NYC, where on the hottest day of the year, everyone's hate and bigotry on single street smolders and builds until they explode into violence. The complex conflicts involve African-Americans, Latinos, Koreans, Italian-Americans and white, middle class yuppies. Ajami (Israel, 2009), set in Jaffa outside of Tel Aviv, is a powerful crime drama set on the streets of a neighborhood that is a melting pot of cultures and conflicting views among Jews, Moslems and Christians and told through the eyes of a cross-sec- 
tion of the city's inhabitants. Directed by both an Israeli (Yaron Shani) and a Palestinian (Scandar Copti), as their stories intersect and the film's narrative shifts back and forth in time, a dramatic collision of different worlds and the tragic consequences of enemies living as neighbors are observed.

\section{Divided or Contested Cities}

Divided or contested cities provide another strong theme in the urban cinema. Carol Reed's The Third Man (UK, 1949) is filmed entirely in post-World War II Vienna while it was still divided, and the ways in which the main characters of a newsman, a mysterious, beautiful woman and a manipulative, black market drug dealer move around the city, including through underground sewers, between the sectors dominated by the Americans and that of the Russians, provides much of the dramatic tension in the film. Tom Tykwer's Run Lola Run (Germany, 1998) is set in Berlin where a young woman has 20 minutes to find and bring a large sum of money to her boyfriend before he robs a supermarket. The fast-paced movie is an engaging mix of live drama and animation offering a number of possible endings and explores routes through the city, which still shows the effects of its long division and isolation during the Cold War. In Peter Weir's The Year of Living Dangerously (USA/Australia, 1982), set in Jakarta, a young Australian reporter tries to navigate the political turmoil of Indonesia during the rule of President Sukarno with the help of a diminutive photographer. The setting during the attempt to install a communist government in Indonesia, and the army's brutal and successful response, demonstrate clearly the dominant political role of large cities in, most notably in developing countries.

\section{Immigration}

Immigration, especially from poor to rich countries, but also from the rural countryside to the big city, is a major thematic trend in cinema. The absorption of immigrants provides drama and pathos, but also humor. In Perry Henzell's The Harder They Come (Jamaica, 1972), notable for its soundtrack highlighting many reggae artists, Ivanhoe Martin comes to Kingston to make it big as a singer. However, he finds life in the city to be harder than he thought, degenerates into criminality and is finally hunted down and killed by the police. Sean Ellis' Metro Manila (UK/Philippines, 2013) is quite similar thematically, but takes place in a far different cultural context. It is an unpredictable movie with a poetic and searingly realistic migrant drama that gradually becomes a crime story, Metro Manila is a thoughtful drama/heist movie set in the Philippines that not only captures a beautiful internal view of the capital's desperate underside, but also delivers some superb twists and turns as the central crime story starts to reveal itself.

Other films on immigration are more positive and uplifting. Clint Eastwood's Grand Torino (USA, 2008) centers on the story of a racist Korean War veteran living in a crime-ridden Detroit neighborhood who is forced to confront his own lingering prejudice when a troubled immigrant Hmong teen from his neighborhood attempts to steal his prized Gran Torino as part of a gang initiation rite. Later, due to the pride of his Asian family, the boy is forced to return to Kowalski's house and perform an act of penance. Despite the fact that Kowalski wants nothing to do with the young troublemaker, the reluctant vet sets him up with an old crony who now works in construction. In the process, Kowalski discovers that the only way to lay his many painful memories to rest is to finally face his own blinding prejudice head-on. It is a telling story of how interaction with immigrants can lead to mutual understanding and respect. Moreover, in Gurinda Chadha's Bend it like Beckham (UK, 2002), the daughter of orthodox Sikh immigrants in London rebels against her parents' traditionalism by running off to Germany with her soccer team. Themes of immigrant integration, the role of women in a changing social milieu and homosexuality in traditional society are humorously explored, with mutual acceptance the ultimate outcome.

\section{Crime Dramas}

Other urban centered films are pure crime dramas. American and French films have long dominated this genre, but two films demonstrate the global reach of this theme. Java Heat, directed by Conor Allyn (USA/Indonesia, 2013) centers on the aftermath of a suicide bombing in Yogjakarta, Indonesia, where a reckless American posing as a grad student is bent on vengeance but quickly finds that the world's problems can't be solved with violence alone. This mysterious American Marine/FBI agent teams with a Muslim cop to hunt down a dangerous international jewel thief who kidnaps a Sultan's daughter in a plot to steal the royal treasury. It is a story of exotic intrigue amid ancient palaces, mosques, temples, subterranean labyrinths and stone pyramids in the heart of 
Java's most important cultural center. Viva Riva! (Congo, 2010), directed by Djo Munga, is another rarity. Set in Kinshasa, this is a noir Congolese crime film full of guns, sex and money. It is good, entertaining viewing as a Congolese gang steals a truckload of gasoline from an Angolan crime lord, who then proceeds to Kinshasa to try and get it back. It accurately portrays the feel and look of a major African capital and is filmed entirely in Kinshasa.

Nevertheless, a crime drama can have deeper meaning. Roman Polanski's Chinatown (USA, 1974) is very complex. It not only explores the darkest of human sins-incest-but the plot revolves around the murder of a planner within the context of the water wars that transformed Los Angeles from a sleepy Western backwater to a global multi-ethnic metropolis. Urban history comes to the fore here, along with the fear of Chinese immigrantsperhaps a portent of current controversy.

Yet an urban crime drama can also be light. Dibakar Banerjee's Detective Byomkesh Bakshy! (India, 2015) is an example. This well reviewed film is an action mystery thriller based on a character created by a Bengali writer and made popular in a television show of the 1990s. In a contemporary interpretation of war-torn Calcutta in the 1940s, the plot follows the adventures of Byomkesh, fresh out of college. He is a socially awkward youngster with a raw, analytical mind who is transformed into a great detective at a time when Japanese and Chinese agents and smugglers were engaged in covert activities to usurp the city from British control to get a foothold in the Indian and Burmese markets.

\section{Urban Fantasies}

Thematically, moreover, the city can also occur in fantasies. Ernesto Alemany's La Gunguna (Dominican Republic, 2015) tours the Santo Domingo underground leaving a trace of bad luck and unfortunate events, marked with tones of black humor. A pistol passes through the hands of a parade of bizarre characters-lowlifes, loan sharks, gun traffickers, professional pool and domino players, corrupt military men-moved by vengeance and deception, weaved together in episodes of tension, violence, even reflection, in an ironic and picturesque society where "La Gunguna" becomes a bad omen, showing how curses are sometimes disguised under a shiny coat of gold. Wild City (Hong Kong/China, 2015), made by master Hong Kong filmmaker Ringo Lam, is unhurried, stylish, neo-noir and completely unreal. Driven by a jaded lead protagonist, the movie is visually stunning with spectacular images of the city providing the context. The cool anti-hero is a bartender and haunted ex-cop who reminds the viewer of Jason Bourne or Jack Reacher and similarly entices one to hope for a sequel. Black Orpheus (Brazil/France/Italy, 1959), directed by Marcel Camus and set in Rio de Janeiro, is another Latin-tinged fantasy about the urban experience. The film retells the Greek myth of Orpheus and Eurydice against the madness of Carnival in Rio. It introduced the bassa nova sound to the US and has a beautiful soundtrack that enhances the fabulous color photography of a beautiful city.

\section{The Arts}

Film also shows how the city provides support to the arts through its concentration of artists and performers. This proximity enables the city to be a nexus for creativity that spans photography to painting to design (fashion, transportation, graphic, digital) to sculpture to musical composition and performance to theater and to cinema itself. Art in the public sphere can only take place in the city. Ahmad Abdalla's Microphone (Egypt, 2011) is part fiction, part documentary, and is a love letter to the underground arts scene in Alexandria. The participants are hip-hop singers who perform on sidewalks, female rock musicians on rooftops, skateboarders cruising all over the city, graffiti artists who confront the city with their shocking murals in the darkness of the night. The movie is a vibrant image of this colorful music and art movement. It is a real narrative of this new generation of artists from Alexandria and the intricate details of their lives. This is a classic urban film. The city matters.

\section{Romance}

It matters as well in Piter FM. Three Episodes (Russia, 2006), directed by Oksana Bychkova. This movie is the epitome of a modern Russian romance. It really captures the feel of the great city of St. Petersburg, as well as having a very Russian take on love and friendship. The movie is beautifully shot, and the city is wonderful with fantastic architecture. In the film, the city is bright, moving, a city with a smile—-sometimes kind, sometimes sad or ironical—but always the only place that the romance between a disk jockey and an architect could take place. 
It completely obliterates one's image of Russian cinema as heavy, dark and depressing, while highlighting classic Russian architecture in the country's most captivating city.

\section{Politics and Culture}

Finally, cinema is often the vehicle to point out important political and cultural issues. On the Waterfront (USA, 1954), directed by Elia Kazan, focuses on labor union violence and corruption among longshoremen while detailing widespread corruption, extortion, and racketeering within the union leadership on the New York City waterfront of Hoboken, New Jersey. It brought significant attention to this issue and, in 1997, it was ranked by the American Film Institute as the eighth-greatest American movie of all time and was deemed by the Library of Congress as "culturally, historically or aesthetically significant" by and selected for preservation in the United States National Film Registry. The Istanbul based Can (Turkey, 2011), directed by Rasit Çelikezer, centers on themes of family and masculinity, so important in Moslem Turkey. A young couple yearns to have a baby, but when the husband discovers he is sterile, he pressures his wife into faking a pregnancy while they secretly adopt a baby boy named Can. The film effectively moves back and forth between these events and a second timeframe set seven years later, when the wife, scarred by the circumstances of her "maternity" and her husband's subsequent desertion, withholds the love that Can so desperately needs. The secretive nature of the adoption and the fates of the main characters form not only a poignant Turkish story, but a uniquely urban one.

\section{Conclusion}

Commercial cinema, despite constant technological change, shorter attention spans and the many alternative forms of entertainment available in the $21^{\text {st }}$ century retains its vitality as an art form that speaks to the urban way of life. It is visual and colorful, with textures of light and sound. Yet a film's length can both maintain a storyline and explore a social, political, cultural or human issue. It is a complex and challenging art form that reflects its urban context, and it is one that spans the globe. It has a special role in exploring urban issues, and generations of moviemakers have kept that function alive as they have redefined the medium to fit their time. That tradition continues.

\section{References}

Ajami (Israel, 2009). Produced by Moshe Danon, Thanassis Karathanos and Talia Kleinhendler and Directed by Scandar Copti and Yaron Shani.

Bend it like Beckham (UK, 2002). Produced by Gurinda Chadna and Deepak Naya and Directed by Gurinda Chadna.

Black Orpheus (Brazil/France/Italy, 1959). Produced by Sacha Gordine and Directed by Marcel Camus.

Blade Runner (USA, 1991). Produced by Charles de Lauzirika and Michael Deeley and Directed by Ridley Scott.

Can (Turkey, 2011). Produced and Directed by Rasit Çelikezer.

Chinatown (USA, 1974). Produced by Robert Evans and Directed by Roman Polanski.

City of God (Brazil, 20002).Produced by Andrea Barata Ribeiro and Directed by Fernando Meirelles and Kátia Lund.

Detective Byomkesh Bakshy! (India, 2015). Produced by Dibakar Banerjee and Aditya Chopra and Directed by Dibakar Banerjee.

Do the Right Thing (USA, 1989). Produced and Directed by Spike Lee.

Elysium (USA, 2013). Produced by Bill Block, Neill Blomkamp and Simon Kinberg and Directed by Neill Blomkamp.

Grand Torino (USA, 2008). Produced by Clint Eastwood, Bill Gerber and Robert Lorenz and Directed by Clint Eastwood. Java Heat (USA/Indonesia, 2013). Produced by Conor Allyn and Rob Allyn. and Directed by Conor Allyn.

La Gunguna (Dominican Republic, 2015). Produced by Ernesto Alemany and Juan Basanta and Directed by Ernesto Alemany.

La Haine (France, 1995). Produced by Christophe Rossignon and Directed by Mathieu Kassovitz.

Metro Manila (UK/Philippines, 2013). Produced by Mathilde Charpentier and Sean Ellis and Directed by Sean Ellis.

Metropolis (Germany, 1927). Produced by Erich Pommer and directed by Fritz Lang.

Microphone (Egypt, 2011). Produced by Khaled Abol Naga and Mohamed Hefzy and Directed by Ahmad Abdalla.

Modern Times (USA, 1936). Produced and Directed by Charlie Chaplin. 
Norma Rae (USA, 1979). Produced by Tamara Asseyev and Alexandra (Alex) Rose and Directed by Martin Ritt.

On the Waterfront (USA, 1954). Produced by Sam Spiegel and Directed by Elia Kazan.

Piter FM. Three Episodes (Russia, 2006). Produced by Elena Glikman, Aleksandr Rodnyanskiy and Igor Tolstunov and Directed by Oksana Bychkova.

Run Lola Run (Germany, 1998). Produced by Stefen Arndt, Gebhard Henke and Andreas Schreitmüller and Directed by Tom Tykwer.

Slumdog Millionaire (UK/India, 2008). Produced by Christian Colson and Directed by Danny Boyle.

The Harder They Come (Jamaica, 1972). Produced by and Directed by Perry Henzell.

The Third Man (UK, 1949). Produced by Carol Reed, Alexander Korda and David O. Selznick, and Directed by Carol Reed.

The Year of Living Dangerously (USA/Australia, 1982). Produced by James McElroy.and Directed by Peter Weir.

Viva Riva! (Congo, 2010). Produced and Directed by Djo Munga.

Wild City (Hong Kong/China, 2015). Produced by Ringo Lam and Chris Liu and Directed by Ringo Lam. 